\title{
Study of Use of Bitumen Fiber to Increase Flexural Strength of Concrete
}

ISSN: 2639-0574

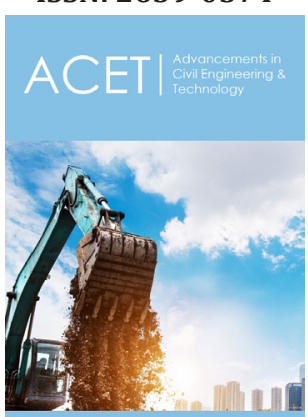

${ }^{* 1}$ Corresponding author: Pandey I, Civil Engineering Department, India

Submission: 梅 September 26, 2019

Published: 制October 15, 2019

Volume 3 - Issue 5

How to cite this article: Pandey I, Sharma A. Study of Use of Bitumen Fiber to Increase Flexural Strength of Concrete. Adv Civil Eng Tech. 3(5). ACET.000571.2019. DOI: 10.31031/ACET.2019.03.000571

Copyright@ Pandey I, This article is distributed under the terms of the Creative Commons Attribution 4.0 International License, which permits unrestricted use and redistribution provided that the original author and source are credited.

\author{
Pandey I* and Sharma A \\ Civil Engineering Department, India
}

\begin{abstract}
There is sudden increase in blast phenomenon either due to terrorist attack or due to accidents. As a result, security and safety of structure becomes more important and considering blast load in design aspect of structure. One of the ways to increase the concrete strength is to increases the size of the member which will increase the stiffness of the structure and the uplift force below the foundation, but this not only increase the economy but also the factor of limited area will be restrain. This objective of this study is to find the mechanical strength of concrete which can withstand impact and blast loads. In this paper use of use of high-performance concrete is used along with bitumen fiber to give large deformation. Main focus was to increase the ductility of concrete and strong enough to resist blast impact loads without failure. Use of such concrete will considerably affect the economy of the structure by reducing the dimension of the members.
\end{abstract}

Keywords: Use of bitumen fiber; Increasing flexibility and ductility; Decreasing standoff distance; Use of rice husk; HPC; Minimizing cost of construction

\section{Introduction}

Since the time of World War, I there was increase in demand of development of blast resistance structure. It is during World War II the defense organizations took keen interest and funded the researchers carried on RCC structures subjected to blast loading [1]. The application of blast loading on structures affects the walls, columns, beams and slabs by impact waves. Therefore, a structural designer must ensure the failure of structure in ductile manner. The building constructed in Oklahoma City using non ductile concrete design proved to be extremely dangerous [2]. In high rise buildings due to decrease in wavelength the impact loading the time period increases. So, to reduce the effect of blast loading the size of the beam column is increased. Another approach to tackle the blast load is to add shear wall and bracings but as result the cost of the construction increases. Another way to reduce the effect is to use columns at closer distance at or near the ground. The columns are also sometimes wrapped with carbon fiber reinforced sheets, but it then affects the economy of the construction. Many researchers have shown in their research that the cost of construction of blast resistance of new structures is far overpriced than the cost required for retrofitting of a present structure to same standards [1]. The main damage mechanics of an explosion is supersonic shock waves that transmit radially from the blast origin like a bubble. The blast which occur at or near the earth's surface, ground waves also take place and are handled similar to seismic waves [1]. The use high performance concrete (above M60) has added advantages over conventional concrete due to high compressive strength, low porosity, improved microstructural homogeneity, high flexibility with addition of fibers [3]. The design of high-grade concrete was made achievable by reduction of micro-cracks in the hydrated cement paste and the transition zone which results in reduction of porosity and reducing in homogeneity in the normal concrete [3].

Rice husks are shells generating during the de-husking of paddy rice. A per recent data $1000 \mathrm{~kg}$ of paddy rice produces about $200 \mathrm{~kg}$ of husk, which on burning generate about $40 \mathrm{~kg}$ of ash [4]. Both the crystalline and amorphous rice husk ash is used to manufacture a limerice husk ash mix and Portland rice husk ash cement. Replacement of OPC by rice husk ash 
significant improvement in flexural strength and compressive strength for M30 and M60 grade of concrete. Both concrete mixes at $10 \%$ replacement level of rice husk ash level showed 0.6 to $8 \%$ increase in flexural strength. There is decrease in split tensile strength in both grades of concrete mixes. It varies from $9.7 \%$ to $26.69 \%$ and 6.62 to $26.90 \%$ at 28 days for the variation for rice husk content 5 to $20 \%$ from M30and M60 grade of concrete [4]. The addition of rice husk ash increases compressive strength of concrete at $10 \%$ replacement of cement. Due to increase in demand of cement in the construction day by day, the scientist start to use the waste material in the construction purpose (such as- flash ash, rice husk ash, marble powder, polymers, waste plastics, E-waste, etc) to prevent from the overburden on nature resources.

\section{Main Objective}

The objective of this paper to increases the flexural strength of concrete and give low shrinkage, low permeability, and high compressive strength by the addition of bitumen fibers and rice husk ash in the high strength concrete (M60).

\section{Methodology}

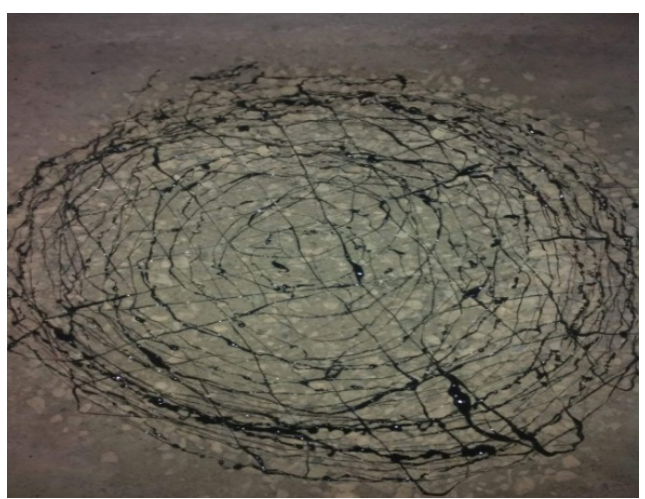

Figure 1: Bitumen fiber over the mixture.

In this experimental program the M60 design mix concrete was taken [5], the concrete is made with the water-cement ratio of 0.45 . The cement is replaced with the VG-10 bitumen and Rice Husk Ash (RHA) in different proportions, and the bitumen is collected from the local Public Works Department of Bareilly, U.P. and the RHA is collected from the rice mill of a Bareilly. The Portland Pozzolana

Table 2: Mix proportion of materials
Cement of 43 grade is used, which is collected from the local distributer of Bareilly. The RHA is passed from the 45 micron sieve [5] and the threads of bitumen is made the help of metallic cone, the cone having hole of $1-2 \mathrm{~mm}$ diameter; the molten bitumen is passed from the cone and it is separated over the mixture (coarse aggregate, fine aggregate, cement and RHA) of minerals and allow to cool down for some time. After cooling of bitumen threats, water is added to prepare the concrete (Figure 1). Long threads are automatically broken into small fibers and a uniform mixture is prepared [6-8].

By using these materials, the concrete cube $(150 * 150 * 150 \mathrm{~mm})$ and beam mould $(100 * 100 * 500 \mathrm{~mm})$ is casted and tested after 28days in the compression testing machine and flexibility testing machine. The Table 1 shows the initial tests made on bitumen to find the flash point, fire point, penetration and ductility so that when used in high temperature areas, it gives the desired results. The tests showed that that bitumen can withstand the high environmental temperature [9-11].

Table 1: Physical properties of bitumen.

\begin{tabular}{|c|c|c|}
\hline S No. & Properties of Bitumen & (VG-10) \\
\hline 1 & Flash Point & $195^{\circ} \mathrm{C}$ \\
\hline 2 & Fire Point & $210^{\circ} \mathrm{C}$ \\
\hline 3 & Penetration & $18.42 \mathrm{~mm}$ \\
\hline 4 & Ductility & $71.33 \mathrm{~cm}$ \\
\hline
\end{tabular}

The design mix shown in Table 2 has given satisfactory results. The tests were performed in control condition wherein cement is replaced by bitumen and rice husk ash in stated ratio and the flexural strength of concrete increased by $1.28 \mathrm{MPa}$. The design mix shown in Table 3 has given satisfactory results. The tests were performed in control condition wherein cement is replaced by bitumen and rice husk ash in stated ratio and the flexural strength of concrete increased by 4.88MPa [12-15]. The design mix shown in Table 4 has given satisfactory results. The tests were performed in control condition wherein cement is replaced by bitumen and rice husk ash in stated ratio and the flexural strength of concrete increased by $16.68 \mathrm{MPa}$.

\begin{tabular}{|c|c|c|c|c|c|}
\hline Mix & $\begin{array}{c}\text { Design Mix of M60 } \\
\text { Grade (in Gram) }\end{array}$ & $\begin{array}{l}\text { Compressive Strength } \\
\text { in MPa at 28Days }\end{array}$ & $\begin{array}{c}\text { Flexural Strength of } \\
\text { Design Mix in MPa at } \\
\text { 28Days }\end{array}$ & $\begin{array}{l}\text { Flexural Strength } \\
\text { of } \mathrm{M60} \text { grade } \\
\text { concrete MPa }\end{array}$ & $\begin{array}{l}\text { Increase in Flexural } \\
\text { strength } \mathrm{MPa}\end{array}$ \\
\hline Bitumen & 15 & \multirow{6}{*}{62.5} & \multirow{6}{*}{6.7} & \multirow{6}{*}{5.42} & \multirow{6}{*}{$6.7-5.42=1.28$} \\
\hline RHA & 85 & & & & \\
\hline Course Aggregate & 2460 & & & & \\
\hline Fine Aggregate & 1240 & & & & \\
\hline Cement & 900 & & & & \\
\hline $\mathrm{W} / \mathrm{C}$ ratio & $450 / 1000$ in liter & & & & \\
\hline
\end{tabular}


Table 3: Mix Proportion of Materials.

\begin{tabular}{|c|c|c|c|c|c|}
\hline Mix & $\begin{array}{l}\text { Design Mix of M60 } \\
\text { Grade (in Gram) }\end{array}$ & $\begin{array}{l}\text { Compressive Strength } \\
\text { in MPa at 28Days }\end{array}$ & $\begin{array}{c}\text { Flexural Strength of } \\
\text { Design Mix in MPa at } \\
\text { 28Days }\end{array}$ & $\begin{array}{l}\text { Flexural Strength of } \\
\text { M60 grade concrete } \\
\text { in MPa }\end{array}$ & $\begin{array}{c}\text { Increase in Flexural } \\
\text { Strength MPa }\end{array}$ \\
\hline Bitumen & 30 & \multirow{6}{*}{61.4} & \multirow{6}{*}{10.3} & \multirow{6}{*}{$0.7 \times \sqrt{\text { fck }}=5.42$} & \multirow{6}{*}{$10.3-5.42=4.88$} \\
\hline RHA & 70 & & & & \\
\hline Course Aggregate & 2460 & & & & \\
\hline Fine Aggregate & 1240 & & & & \\
\hline Cement & 900 & & & & \\
\hline $\mathrm{W} / \mathrm{C}$ ratio & $450 / 1000$ in liter & & & & \\
\hline
\end{tabular}

Table 4: Mix proportions of materials.

\begin{tabular}{|c|c|c|c|c|c|}
\hline Mix & $\begin{array}{l}\text { Design Mix of M60 Grade } \\
\text { (in Gram) }\end{array}$ & $\begin{array}{l}\text { Compressive Strength } \\
\text { in MPa at 28Days }\end{array}$ & $\begin{array}{c}\text { Flexural Strength of } \\
\text { Design Mix in MPa at } \\
\text { 28Days }\end{array}$ & $\begin{array}{c}\text { Flexural Strength of } \\
\text { M60 grade concrete } \\
\text { MPa }\end{array}$ & $\begin{array}{l}\text { Increase in Flexur- } \\
\text { al Strength } \mathrm{MPa}\end{array}$ \\
\hline Bitumen & 60 & \multirow{6}{*}{60.9} & \multirow{6}{*}{22.1} & \multirow{6}{*}{$0.7 \times \sqrt{\mathrm{fck}}=5.42$} & \multirow{6}{*}{$22.1-5.42=16.68$} \\
\hline RHA & 40 & & & & \\
\hline $\begin{array}{l}\text { Course Aggre- } \\
\text { gate }\end{array}$ & 2460 & & & & \\
\hline Fine Aggregate & 1240 & & & & \\
\hline Cement & 900 & & & & \\
\hline $\mathrm{W} / \mathrm{C}$ ratio & $450 / 1000$ in liter & & & & \\
\hline
\end{tabular}

\section{Conclusion}

A. It is concluded that on the addition of bitumen fiber and the rice husk ash in replacement of cement the properties of the M60 grade concrete is enhanced.

B. On replacing the $100 \mathrm{gm}$ of cement by $60 \mathrm{gm}$ of bitumen fiber and 40gm of RHA, the concrete gave the best result.

C. The flexural strength of concrete is increased by $16.68 \mathrm{~N} /$ $\mathrm{mm} 2$ with respect to natural flexible strength of concrete and the compression strength is maintained by the bitumen.

D. By using the specified amount of RHA we can decrease the cost of structure.

E. By using these types of mixture, the standoff distance should be decreased, because this M60 concrete have high flexibility.

F. It should be possible to decrease the voids in the concrete; the particle size of RHA (45micron) is less than cement.

G. By using RHA and bitumen it should be possible to make the HPC at low cost.

H. By using this type of concrete the chances of collapse of structure during the blast should be reduced due to impact waves of blast.
Scope of the Study

The study was made by taking a pre-defined concrete mix of M60.The same can be performed for low grade of concrete. Such concrete can also be utilized in building construction.

\section{References}

1. Ali MM (2002) Protective design of concrete buildings under blast loading. In: Jones N, Brebbia CA, Rajendran AM (Eds.), WIT PressStructures under Shock and Impact VII, USA.

2. Liskay Z, Rugg S, Thompson C (2014) Blast resistant building design: building behavior and key elements. Lehigh Preserve 22: 5 .

3. Indu L, Sanjeev N, Rajeev S (2017) Design of high-performance concrete (HPC) M100 using mineral admixture (Alccofine-1203) and fly ash. International Interdisciplinary Conference on Science Technology Engineering Management Pharmacy and Humanities.

4. Abhilash S, Singh CK, Sharma AK (2011) Study of the properties of concrete by partial replacement of ordinary Portland cement by rice husk ash. International Journal of Earth Sciences and Engineering 4(6): 965-968.

5. Zealakshmi D, Ravichandran A, Kothandaraman SK (2014) Strength modeling of high strength concrete. IOSR Journal of Mechanical and Civil Engineering (IOSR-JMCE) 11(3): 57-61.

6. Ashalekshmi KG, Subha K (2018) A review on the study of the response of ground blast loads on RCC structures. International Research Journal of Engineering and Technology (IRJET) 5(4). 
7. Gautham TN, Hegde MN (2017) Blast resistant buildings. International Research Journal of Engineering and Technology (IRJET) 4(9): 11561159.

8. Chandrashekhar, Inamdar NS (2017) Analysis of blast resistance structure. International Research Journal of Engineering and Technology (IRJET) 4(8): 1807-1814.

9. Swamini TG, Shirsath MN (2017) Study of blast analysis for structural building. International Research Journal of Engineering and Technology (IRJET) 4(8): 1310-1316

10. Meghanadh M, Reshma T (2017) Blast analysis and blast resistant design of R.C.C residential building. International Journal of Civil Engineering and Technology (IJCIET) 8(3): 761-770.

11. George D, Varnitha MS (2016) Structural analysis of blast resistant structures. IJSRD-International Journal for Scientific Research \& Development 4(5): 1141-1144.
12. Manjunath BH, Pradeep Kumar AV, Rahulraj M (2016) High-volume high-performance fly ash concrete mix design for pavement overlays for sustainable development. International Journal of Civil Engineering and Technology (IJCIET) 7(6): 592-601.

13. Raghucharan MC, Prasad MLV (2015) How to make concrete more ductile-a state of art. International Journal of Engineering and Technical Research (IJETR) 3(5): 349-354.

14. Srivastava S, Jain SS, Chauhan MPS (2014) Structural behavior of high strength high performance concrete pavement under heavy loads International Journal of Engineering Research \& Technology (IJERT) 3(10): 893-899.

15. Priya KV, Brammananadham GG, Sri Gnana Prakash P, Vinoth Kumar G, Santha Kumar M (2016) Study of coir fibre reinforced bituminous mixes with anti-stripping agent. International Journal of Science and Innovative Engineering \& Technology. 